Jurnal Kebidanan dan Keperawatan 'Aisyiyah, 17 (2), 2021, 294-303

\title{
Strategi pemberdayaan kader dengan inovasi ginger hot pack untuk menurunkan tekanan darah dan kolesterol
}

\section{Cadre's empowerment strategy with ginger hot pack innovation to reduce blood presurre and cholesterol level}

\author{
Indrayanti $^{1^{*}}$, Antonius Yogi Pratama ${ }^{2}$, Nining Indrawati ${ }^{3}$ \\ 1,2,3 STIKES Bethesda Yakkum, Yogyakarta \\ 1indrayanti@stikesbethesda.ac.id*; ${ }^{2}$ yogi@ stikesbethesda.ac.id; ${ }^{3}$ nining@ stikesbethesda.ac.id \\ *corresponding author
}

Tanggal Submisi: 2 November 2020, Tanggal Penerimaan: 14 Juni 2021

\begin{abstract}
Abstrak
Studi ini bertujuan untuk merancang strategi pemberdayaan kader kesehatan melalui inovasi ginger hot pack sebagai perawatan rumah untuk menurunkan tekanan darah dan kolesterol. Penelitian ini menggunakan studi quasi eksperimen dengan desain time series. Subyek penelitian adalah kader kesehatan. Teknik pengambilan sampel dengan purposive sampling. Pelatihan kader dilaksanakan pada minggu pertama, kemudian kader mengajarkan pada klien hipertensi mengenai penggunaan ginger hot pack, dan melakukan pengukuran tekanan darah dan kolesterol pada minggu ke-2 dan ke-3. Hasil penelitian menunjukkan bahwa ada penurunan tekanan darah secara signifikan dengan nilai $\mathrm{p}=0,001$. Terjadi penurunan kolesterol dengan $\mathrm{p}=0,57$ tetapi tidak signifikan. Kesimpulan dalam penelitian ini adalah strategi pemberdayaan kader dengan ginger hot pack dapat menurunkan tekanan darah.
\end{abstract}

Kata kunci: hipertensi; ginger hot pack; tekanan darah; kolesterol; pemberdayaan kader

\begin{abstract}
This study aims to design health cadre empowerment strategy with ginger hot pack innovation to reduce blood pressure and cholesterol level. It was a quasiexperiment study with time series design. The research subject was health cadres. The sampling technique was purposive sampling technique. The researcher gave a training to cadres in the first week. Afterward, the cadres gave a training to hypertension client about the use of ginger hot pack and measured the blood pressure and cholesterol level on the second and the third week. There is a significant decrease in systolic blood pressure $(p=0.001)$ and there is no significant difference in diastolic blood pressure $(p=0.006)$. There is a decrease in cholesterol level ( $p=0.57)$, but it is not significant.
\end{abstract}

Keywords: hypertension; ginger hot pack; blood pressure; cholesterol; cadre's empowerement 


\section{PENDAHULUAN}

Penyakit tidak menular (PTM) merupakan penyebab kematian hampir $70 \%$ di dunia (World Health Organization, 2019). Menurut hasil Riset Kesehatan Dasar (Riskesda) tahun 2018, dua PTM tertinggi yaitu hipertensi prevalensi penyakit kardiovaskular pada penduduk semua umur menurut propinsi, Daerah Istimewa Yogyakarta (DIY) menempati urutan ketiga, (Riskesdas, 2018). Peningkatan prevalensi hipertensi dari tahun ke tahun menambah beban pembiayaan kesehatan di Indonesia. Data pembiayaan pelayanan kesehatan PTM tahun 2018 salah satunya hipertensi menghabiskan biaya mencapai 20,4 triliun (Kemenkes, 2019).

Hipertensi terjadi akibat perilaku hidup yang tidak terkontrol seperti konsumsi makanan asin dan berlemak, olah raga tidak teratur dan merokok (Alicea \& Planes, 2016), selain itu stres juga beresiko terjadinya hipertensi (Stockert \& Hall, 2013). Faktor resiko lain yang memicu hipertensi adalah peningkatan kadar kolesterol yang disebabkan karena kurangnya aktivitas fisik pada individu (Ruslianti, 2014). Hasil penelitian Susanti et al., (2021) di Yogyakarta, banyak lansia yang mengalami nyeri tengkuk pada hipertensi. Proporsi terbesar klien datang berobat ke pelayanan kesehatan dengan intensitas nyeri sedang skala 4-6 sebesar $60 \%$, dan $29 \%$ merupakan nyeri tengkuk. Nyeri tengkuk merupakan salah satu penyebab utama kecacatan secara global, merupakan diantara 291 kondisi kesehatan lainnya, nyeri tengkuk berada di peringkat ke-4 (Anggara \& Prayitno, 2013).

Hipertensi dapat dikendalikan secara farmakologis dengan obat anti hipertensi dan secara nonfarmakologis dengan terapi komplementer serta modifikasi gaya hidup. Terapi herbal juga merupakan salah satu terapi komplementer. Jahe merupakan terapi herbal yang dapat menimbulkan efek farmakologis berfokus pada peregangan otot menggunakan energi panas dan khasiat jahe itu sendiri, sehingga dari dalam tubuh dapat menghasilkan hormon seperti serotonin dan endorphin relaxan sehingga dapat mengurangi rasa sakit. Efek jahe secara nonfarmakologis dapat mengurangi rasa nyeri kaku dan spasme otot dan mengakibatkan vasodilatasi pembuluh darah membesar sehingga aliran darah menjadi lancer (Indah, Nurhayati dan Setiyajati, 2013).

Upaya pemerintah dalam menurunkan prevalensi hipertensi melalui program kegiatan pos pembinaan terpadu (POSBINDU) PTM. Namun POSBINDU PTM masih belum berjalan secara optimal karena tingkat kesadaran masyarakat masih rendah utuk mengikuti kegiatan tersebut. Seperti pelaksanaan pemantauan di posyandu terkait dengan penyakit PTM maupun lainnya (Syagata et al., 2021).

Berdasarkan wawancara pada kader di salah satu Kelurahan Kota Yogya, kader belum mendapatkan update ilmu secara rutin tentang pengendalian hipertensi di masyarakat maupun pelatihan-pelatihan terkait pengobatan mandiri di rumah. Pemberdayaan kader diperlukan untuk mengoptimalkan perawatan mandiri di rumah (Yandrizal et al., 2016). Selain pengobatan rutin untuk pengendalian tekanan darah juga dapat dilakukan dengan terapi komplementer mengunakan bahan bahan tradisional. Hasil penelitian Nadia (2020) menjelaskan bahwa jahe memiliki khasiat untuk menurunkan tekanan darah karena jahe mengandung converting enzyim yang dapat mennghambat aktivitas angiontensin. 
Penelitian Jusuf \& Sudirman (2018) menunjukkan bahwa terdapat pengaruh rendam air hangat menggunakan jahe dalam penurunan tekanan darah. Perbedaan penelitian ini dengan penelitian lainnya mengunakan ginger hot pack, yaitu jahe diparut basah kemudian dimasukkan ke dalam pack lalu dikompreskan langsung di bawah tengkuk. Inovasi ini diharapkan bermanfaat untuk menurunkan tekanan darah dan menurunkan nyeri tengkuk pada penderita hipertensi.

Pengendalian hipertensi di masyarakat dapat dilakukan dengan salah satu strategi intervensi di komunitas yaitu pemberdayaan. Masyarakat dilibatkan dengan berbagi kegiatan dan diberikan pelatihan agar dapat bermanfaat secara keberlanjutan. Strategi intervensi keperawatan komunitas melalui pemberdayaan masyarakat terlibat secara aktif untuk menyelesaikan masalah.

Kontinuitas pada kader diperlukan dalam pengendalian hipertensi dengan melakukan pemberdayaan kader. Studi ini bertujuan untuk mengetahui penurunan tekanan darah pada orang dengan hipertensi dan mengidentifikasi pengaruh ginger hot pack dalam menurunkan kolesterol di Kota Yogyakarta, merancang standar prosedur operasional (SPO) pembuatan ginger hot pack, merancang strategi pemberdayaan kader kesehatan melalui ginger hot pack sebagai perawatan rumah untuk menurunkan tekanan darah dan kolesterol, serta melakukan pelatihan kader kesehatan untuk inovasi ginger hot pack.

\section{METODE}

Design penelitian ini merupakan quasi experiment dengan pendekatan times series untuk mengukur efek intervensi. Teknik pengambilan sampel menggunakan purposive sampling dengan kriteria inklusi kader kesehatan yang dapat membaca dan menulis dan bersedia menjadi responden. Individu yang akan mendapat terapi ginger hot pack adalah orang dengan hipertensi dan hasil kolesterol tinggi 1 rentang usia 45-65 tahun, pernah mengalami nyeri tengkuk dalam satu bulan terakhir, penderita tidak mengkonsumsi obat atau tidak patuh minum obat. Sampel pada penelitian ini berjumlah 30 responden.

Intervensi dilakukan selama empat minggu. Sebelum diberikan intervensi, kader diukur tingkat pengetahuannya. Pada minggu pertama, kader diberikan pelatihan pembuatan ginger hot pack. Minggu kedua, kader melatih klien hipertensi dalam pembuatan ginger hot pack dan mengajarkan cara penggunaannya. Penggunaan ginger hot pack dengan dikompres pada bagian tengkuk dan dilakukan setiap hari satu kali selama 10 menit pada malam hari atau jika mengalami nyeri. Pengukuran tekanan darah dilakukan pada minggu kedua sampai keempat, sedangkan pengukuran kolesterol dilakukan pada minggu kedua dan keempat. Pada minggu ke empat dilakukan evaluasi tingkat pengetahuan.

Analisis data pengukuran tekanan darah menggunakan uji repeated anova, sedangkan pengukuran kolesterol dilakukan dengan uji paired t-test. Penelitian ini sudah dinyatakan lolos uji etik oleh Komite Etik Penelitian Kesehatan Politeknik Kesehatan Kemenkes Yogyakarta dibuktikan dengan surat lolos etik nomor e-KEPK/POLKESYO/0224/III/2020. 


\section{HASIL DAN PEMBAHASAN}

Pelatihan kader kesehatan mengubah perilaku masyarakat dalam membantu menurunkan tekanan darah dan kolesterol. Berikut ini adalah data karakteristik responden berdasarkan usia, tingkat pendidikan yang disajikan dalam tabel 1.

Tabel 1. Karakteristik responden berdasarkan usia

\begin{tabular}{ccccc}
\hline Variabel & $\mathbf{n}$ & Mean & Min & Maks \\
\hline Umur & 30 & 52,57 & 37 & 74 \\
\hline
\end{tabular}

Tabel 2. Karakteristik responden berdasarkan tingkat pendidikan

\begin{tabular}{lcc}
\hline \multicolumn{1}{c}{ Tingkat Pendidikan } & n & \% \\
\hline Rendah & 6 & 20 \\
Menengah & 19 & 63,3 \\
Tinggi & 5 & 16,7 \\
Total & 30 & 100 \\
\hline
\end{tabular}

Karakteristik rerata usia kader adalah 52 tahun dengan rentang usia 37 tahun sampai dengan 74 tahun. Hasil penelitian ini sejalan dengan penelitian Lusiyana (2020) bahwa 70\% usia kader yang mengikuti pelatihan adalah berusia lebih dari 40 tahun. Karakteristik tingkat pendidikan responden menunjukkan bahwa tingkat pendidikan kader yang paling banyak adalah menengah yaitu setara SMA atau SMK.

Tingkat pendidikan dalam karakteristik responden ini berhubungan dengan tingkat pengetahuan. Dari hasil tingkat pengetahuan diperoleh bahwa tingkat pengetahuan yang terbanyak adalah tingkat pengetahuan tinggi yaitu sebanyak 15 orang $(50 \%)$. Setelah dilakukan pelatihan kader terjadi peningkatan yaitu yang mempunyai tingkat pengetahuan tinggi meningkat menjadi 26 orang $(87 \%)$. Peningkatan pengetahuan dapat dilihat dari tingkat pendidikan. Riset ini juga menunjukkan bahwa pendidikan kesehatan dapat meningkatkan pengetahuan seseorang. Hasil ini sejalan dengan penelitian Susanti et al., (2021) menunjukkan bahwa tingkat pendidikan akan mempengaruhi tingkat pengetahuan seorang individu. Sriyono dalam Ulya, Iskandar dan Susanti et al., (2021) pengetahuan dapat dilihat dari tinggi rendahnya tingkat pendidikan, namun tingkat pendidikan, bukan hanya mempengaruhi tingkat pengetahuan seseorang, namun penerimaan informasi seseorang dapat dipengaruhi.

Tabel 3. Perbedaan tekanan darah sebelum dan sesudah intervensi

\begin{tabular}{lllccc}
\hline \multicolumn{1}{c}{ Variabel Tekanan Darah } & N & Mean & SD & p-value \\
\hline \multirow{2}{*}{ Sistol } & Sebelum intervensi & 30 & 157,3 & 26,14 & \\
\cline { 2 - 5 } & Intervensi minggu ke -2 & 30 & 154 & 20,79 & \\
\cline { 2 - 5 } & Intervensi minggu ke-3 & 30 & 148,9 & 18,07 & 0,001 \\
\hline \multirow{2}{*}{ Diastol } & Sebelum intervensi & 30 & 92,2 & 13,709 & \\
& Intervensi minggu ke -2 & 30 & 90,76 & 9,971 & \multirow{2}{*}{0,06} \\
\cline { 2 - 5 } & Intervensi minggu ke-3 & 30 & 88,53 & 11,53 & \\
\hline
\end{tabular}


Hasil pelatihan kader menunjukkan penurunan tekanan darah setelah diberikan intervensi antara sebelum dan sesudah intervensi pada minggu kedua dan minggu ketiga. Hasil uji analisis mengunakan uji repeated anova test tekanan darah sistol $\mathrm{p}=0,001$ dengan $\mathrm{p}<0,05$, dapat dsimpulkan bahwa ada perbedaan yang signifikan antara sebelum intervensi dan sesudah intervensi pada minggu kedua dan minggu ketiga, dengan selisih rerata tekanan darah sistol sebesar $8,4 \mathrm{mmHg}$. Sedangkan hasil uji analisis tekanan darah diastol $\mathrm{p}=0,06$, hal ini menunjukkan tidak terdapat perbedaan signifikan antara sebelum dan sesudah intervensi pada minggu kedua dan minggu ketiga, dengan selisih rerata tekanan darah diastole sebesar 3,67 mmHg.

Berdasarkan hasil penelitian terdapat perbedaan tekanan darah sistol antara sebelum dan sesudah intervensi pada minggu kedua dan minggu ketiga dengan nilai $p$-value $<0,05$, sedangkan tekanan darah diastol dengan nilai $p$ value $>0,05$. Klien hipertensi mendapatkan terapi nonfarmakologis sebagai inovasi yaitu dengan diberikan ginger hot pack, yang merupakan parutan jahe segar yang dimasukkan ke dalam kemasan yang meresap, sehingga jahe tersebut mengeluarkan cairan di dalam pack tersebut dan menimbulkan efek hangat.

Penelitian Rohimah (2015) menyebutkan bahwa efek panas yang dikeluarkan oleh jahe dapat mendilatasi pembuluh darah sehingga suplai oksigen terpenuhi, sehingga dapat meredakan ketegangan pada area tengkuk. Area tengkuk terdapat arteri dan arteriol yang merupakan pembuluh resistensi utama vaskuler. Jahe mempunyai efek vasodilatator yang berasal dari otot polos yang berjalan sirkuel yang mengelilingi arteriol jika berkontraksi menyebabkan pembuluh darah mengecil yang dapat memperlancar pembuluh darah.

Hal ini didukung penelitian El Gayar et al., (2019) dan penelitian Zadeh \& Kor (2014) yang menyatakan bahwa jahe mengandung berbagai macam senyawa antara lain flavonoid, saponin, fenol. Jahe memiliki kandungan flavonoid yang tinggi sehingga mempunyai efek vasodilatasi. Senyawa ini mengandung efek inhibisi terhadap angiotensin converting enzyme yang dapat menyebabkan pembentukan angiotensin 1 dan 2 berkurang sehingga terjadi vasodilatasi pembuluh darah dan memperlancar sirkulasi darah.

Jahe memiliki konstituen yang aktif di dalam jahe yang berfungsi menurunkan tekanan darah dan beban kerja jantung. Penelitian Guerrero et al., (2012) menjelaskan jahe mempunyai kandungan nitric oxide mempunyai efek vasodilator yang dapat menurunkan tekanan darah. Guerrero juga menjelaskan ekstrak jahe yang berair dapat menurunkan tekanan darah melalui efek penghambatan ganda yang dimediasi melalui stimulasi reseptor muskarinik dan blokade saluran $\mathrm{Ca} 2+$.

Penelitian Zadeh \& Kor, (2014) menjelaskan bahwa jahe mengandung gingerol yang mempunyai efek hangat, yang dapat memperlancar sirkulasi darah. Efek panas yang diberikan jahe menyebabkan dilatasi pembuluh darah sehingga suplai oksigen meningkat dan merelaksasikan pembuluh darah dan dapat menurunkan tekanan darah. Hasil penelitian ini tidak sejalan dengan penelitian Wang et al., (2017) yang menyatakan bahwa ada pengaruh pemberian ekstrak jahe terhadap tekanan darah diastolik setelah dua minggu $(\mathrm{p}=0,015)$, tetapi tekanan darah sistolik tidak terdapat pengaruh yang signifikan $(\mathrm{p}=0,086)$. Hal ini menunjukkan banyak faktor yang mempengaruhi dalam menurunkan tekanan darah, namun ekstrak jahe terbukti dapat menurunkan tekanan darah (Fathona et 
al., 2020). Khasiat yang terdapat pada jahe adalah anti inflamasi dan analgesik yang berfungsi sebagai penghambat biosintesis prostaglandin. Penelitian ini menunjukkan bahwa kandungan yang terdapat dalam jahe menghambat aktivitas siklo oksigenase dan lipo oksigenase dalam asam arakidonat sehingga menyebabkan penurunan jumlah prostaglandin dan leukotrien. Hal ini dapat memperlebar pembuluh darah dan memperlancar aliran darah.

Hasil penelitian menunjukkan bahwa pemberdayaan kader yang dilakukan dengan pemberian ginger hot pack dapat menurunkan tekanan darah sistol namun masih terdapat perbedaan yang belum signifikan pada tekanan darah diastol. Hal ini didukung oleh penelitian Jessica (2016) yang menyatakan bahwa banyak faktor resiko pada hipertensi seperti perilaku hidup tidak sehat (merokok, konsumsi tinggi lemak dan kurang olah raga). Sejalan dengan penelitian Pratama (2019) yang menjelaskan bahwa faktor lain yang dapat meningkatkan perawatan diri hipertensi sehingga dapat menurunkan tekanan darah adalah dukungan keluarga.

Penurunan tekanan darah pada klien hipertensi dipengaruhi banyak faktor antara lain perilaku hidup sehat dan dukungan keluarga. Sejalan dengan penelitian Wijaya, (2017) yang menyatakan bahwa penurunan tekanan darah dipengaruhi oleh banyak faktor. Berdasarkan uji statistik didapatkan hasil bahwa terdapat hubungan antara usia, jenis kelamin, riwayat keluarga, konsumsi garam, konsumsi lemak, merokok dan konsumsi alkohol terhadap kejadian hipertensi.

Perilaku individu mempengaruhi perubahan tekanan darah. Strategi pemberdayaan kader yang dilakukan bertujuan untuk meningkatkan pemahaman klien hipertensi dalam melakukan gaya hidup sehat. Pada penelitian ini kader diberikan pelatihan agar dapat memberdayakan masyarakat dalam melakukan perawatan hipertensi dengan menggunakan ginger hot pack. Menurut Stanhope dan Lancaster (2016) penyelesaian masalah yang ada di komunitas dapat melibatkan kader secara langsung.

Dalam penelitian ini strategi pemberdayaan yang diberikan pada kader kesehatan adalah dengan edukasi terkait pencegahan dan perawatan hipertensi, selanjutnya kader-kader kesehatan dilatih membuat ginger hot pack serta kegunaannya. Hasil penelitian menunjukkan peningkatan pengetahuan kader kesehatan sebesar $61 \%$ dan hasil observasi pada kader kesehatan melalui buku kerja kader $100 \%$. Kader memantau klien hipertensi setiap hari dan memberikan ginger hot pack. Hal ini menunjukkan bahwa pemberdayaan kader kesehatan berpengaruh terhadap penurunan tekanan darah pada klien hipertensi, hal ini didukung oleh Nies \& Ewen (2015) yang menyatakan pemberdayaan merupakan keseluruhan upaya untuk meningkatkan kontrol dalam pengambilan keputusan dalam melakukan tindakan. Pemberdayaan kader dengan melatih pembuatan ginger hot pack merupakan terapi non farmakologis, ini sejalan dengan penelitian (Barrera, 2018)bahwa terapi non farmakologis cenderung menurunkan rata-rata 17-27\% tekanan darah sistol pada klien dengan tekanan darah tinggi.

Hasil penelitian diperoleh bahwa pemberdayaan kader dengan melatih kader dapat menurunkan tekanan darah pada orang dengan hipertensi. Sejalan dengan penelitian (El Gayar et al., 2019) bahwa model pemberdayaan dapat membangun kepercayaan diri, kapasitas dan sistem. Pemberdayaan yang diberikan pada kader kesehatan dapat menunjukkan partisipasi masyarakat dalam 
meningkatkan perilaku sehat, hal ini ditunjukkan dengan hasil peningkatan status kesehatan.

Sejalan dengan hasil penelitian ini bahwa pemberdayaan yang diberikan pada kader meningkatkan kepercayaan diri kader dalam memberikan pemahaman kepada masyarakat mengenai pengendalian tekanan darah, yang ditunjukkan dengan pengisian buku kerja kader terisi setiap hari dan catatan pemantauan penggunaan ginger hot pack untuk klien hipertensi terisi 100\%. Prinsip dasar pemberdayaan komunitas adalah komunitas menetapkan agenda/kegiatan mereka sendiri. Partisipasi komunitas merupakan elemen penting dalam melibatkan anggota masyarakat mengembangkan kegiatan yang berfungsi sebagai kekuatan untuk memobilisasi masyarakat menuju proses perubahan.

Tabel 4. Perbedaan nilai kolesterol sebelum dan sesudah intervensi

\begin{tabular}{lcccc}
\hline \multicolumn{1}{c}{ Variabel Kolesterol } & n & Mean & SD & p-value \\
\hline Sebelum intervensi & 30 & 174,13 & 44,26 & \\
\cline { 1 - 4 } Sesudah intervensi & 30 & 169,76 & 41,65 & 0,57 \\
\hline
\end{tabular}

Penelitian ini menunjukkan hasil analisis penurunan kolesterol setelah diberikan intervensi sebesar $\mathrm{p}=0,57$ dimana tidak ada perbedaan signifikan antara sebelum dan sesudah intervensi. Hasil penelitian ini mempunyai persamaan dengan penelitian Pourmasoumi et al., (2018), bahwa pemberian ekstrak jahe tidak berpengaruh signifikan terhadap penurunan kolesterol. Hal ini di dukung oleh penelitian (Amirhossein Sahebkar, 2017) yang menyatakan bahwa dari beberapa penelitian menunjukkan pada jahe tidak ditemukan efek yang menguntungkan untuk penurunan kolesterol.

Hasil penelitian yang dilakukan El Gayar et al., (2019) menunjukkan bahwa terjadi penurunan kolesterol total pada individu setelah diberikan ekstrak jahe bubuk dengan $\mathrm{p}<0,001$. Hasil penelitian tersebut juga menunjukkan bahwa jahe adalah ramuan herbal yang aman yang sering digunakan oleh negara Asia, secara tradisional sering mengobati penyakit hipertensi dan hiperlipidemia. Hasil penelitian Soleha (2012) menunjukkan bahwa tekanan darah sistolik dan diastolik yang tinggi mempunyai kecenderungan hiperkolesterol. Hal ini ini sejalan dengan hasil penelitian bahwa dari 30 responden yang mempunyai tekanan darah tinggi juga memiliki kolesterol yang tinggi. Banyak faktor yang menyebabkan peningkatan kolesterol selain dari peningkatan tekanan darah, gaya hidup juga berperan penting terhadap peningkatan kolesterol. Penelitian Sari \& Rahayuningsih (2014) menyampaikan bahwa modifikasi diet berperan penting dalam penurunan kolesterol.

Jahe merupakan obat tradisional yang mengandung berbagai macam zat terutama memiliki kandungan antioksidan. Hal tersebut menyebabkan peningkatan enzim $\alpha$-hydroxylase yang berfungsi merubah kolesterol menjadi asam empedu dan mengakibatkan kolesterol keluar dari tubuh (Sari \& Rahayuningsih, 2014). Jahe bermanfaat untuk meningkatkan antioksidan dan menurunkan lipid peroksidasi. Hasil penelitian Ifora et al. (2016) menunjukkan ada perbedaan rerata perubahan kadar kolesterol LDL yang bermakna $(\mathrm{p}<0,05)$.

Berbeda dengan penelitian Sari \& Rahayuningsih (2014) yang menunjukkan dengan memberikan jahe yang diminum selama 21 hari dapat 
menurunkan kadar kolesterol, pemberian ginger hot pac pada klien selama tiga minggu dengan cara dikompres di area tengkuk memberikan sumber panas namun tidak langsung memberikan efek di dalam tubuh. Penelitian Wang (2017) menjelaskan bahwa konsumsi jahe dapat menurunkan resiko hiperlipidmia yang ditandai dengan peningkatan konsentrasi trigliserida plasma dan penurunan kolesterol lipoprotein densitas tinggi.

Jahe merupakan tanaman herbal yang digunakan sebagai terapi komplementer untuk membantu menurunkan kolesterol. Modifikasi gaya hidup seperti makanan tinggi serat, olah raga teratur dan mengelola stres juga berperan penting untuk mengontrol pengendalian kolesterol pada individu (Soleha, 2012).

\section{SIMPULAN}

Karakteristik kader di Kota Yogyakarta rerata usia 52 tahun, dengan tingkat pendidikan menengah. Terdapat penurunan rerata tekanan darah sesudah diberikan intervensi sebesar $8,4 \mathrm{mmHg}$ pada sistolik dan 3,67 $\mathrm{mmHg}$ pada diastolik. Penurunan kolesterol tidak terlihat secara signifikan.

\section{DAFTAR PUSTAKA}

Amirhossein Sahebkar. (2017). Views 56 crossref citations to date 4 altmetric articles effects of quercetin supplementation on lipid profile: a systematic review and meta-analysis of randomized controlled trials. Critical Reviews in Food Science and Nutrition, 57. https://doi.org/https://www.tandfonline.com/doi/abs/10.1080/10408398.2014 .948609

Anggara, D., \& Prayitno, N. (2013). Faktor-faktor yang berhubungan dengan tekanan darah di Puskesmas Telaga Murni Cikarang Barat tahun 2012. Dalam Mengamati Perjalanan Epidemiologi Hipertensi di Indonesia, volume 5(1), 20-25. https://doi.org/10.1002/9781444324808.ch36.

Barrera, L. (2018). High blood pressure prevention and control: grom evidence to action. Colombia Medica, 49(2), 137-138. https://doi.org/10.25100/cm.v49i2.3940

El Gayar, M. H., Aboromia, M. M. M., Ibrahim, N. A., \& Abdel Hafiz, M. H. (2019). Effects of ginger powder supplementation on glycemic status and lipid profile in newly diagnosed obese patients with type 2 diabetes mellitus. Obesity Medicine, $14 \quad$ (October 2018). https://doi.org/10.1016/j.obmed.2019.100094.

Fathona, Difa, Wijaya, \& Hanny, C. (2020). Kandungan gingerol dan shogaol, intensitas kepedasan dan penerimaan panelis terhadap oleoresin jahe gajah (Zingiber officinale var. Roscoe), jahe emprit (Zingiber officinale var. Amarum), dan jahe merah (Zingiber officinale var. Rubrum). Repsitory IPB. 2011 Aug. 5-6 2017. Role of the Immune System in Hypertension. http://repository.ipb.ac.id/handle/123456789/51192. 
Ifora, Dharma, Surya, Diken, \& Darma, M. (2016). Pengaruh pemberian kombinasi jahe merah, bawang putih, apel, lemon dan madu terhadap kadar kolesterol total dan histopatologis pembuluh darah aorta jantung tikus putih jantan. Jurnal Farmasi Hyegea, 8. http://jurnalfarmasihigea.org/index.php/higea/article/view/148.

Jusuf, M. I., \& Sudirman, A. N. (2018). Pengaruh terapi rendam air hangat dan air hangat jahe terhadap penurununan tekanan darah pada pasien hipertensi di puskesmas telaga biru. Zaitun (Jurnal Ilmu Kesehatan), 6. https://journal.umgo.ac.id/index.php/Zaitun/article/view/1169.

Ligia Guerrero 1, Castillo, J., Quiñones, M., Garcia-Vallvé, S., Arola, Lluis, \& Gerard Pujadas, B. M. (2012). Inhibition of angiotensin-converting enzyme activity by flavonoids: structure-activity relationship studies. National Library of Medicine, 2. https://doi.org/doi: 10.1371/journal.pone.0049493

Nadia, E. A. (2020). Efek pemberian jahe terhadap tekanan darah pada pasien hipertensi. Jurnal Medika Hutama, 02(01), 343-348. https://jurnalmedikahutama.com/index.php/JMH/article/view/87.

Pratama, A. Y. (2019). Family Involvement in the Treatment of Hypertensive Patients using Dunn's Health Grid: A Multiple Case Study. 13 (Ichs 2018), 20-37. https://doi.org/10.2991/ichs-18.2019.5.

Sari, R. P., \& Rahayuningsih, H. M. (2014). Pengaruh pemberian jahe merah (Zingiber Officinale Var Rubrum) terhadap kadar kolesterol total wanita dislipidemia. In Journal of Nutrition College (Vol. 3, Issue 4). https://doi.org/10.14710/jnc.v3i4.6883.

Siti Rohimah. (2015). Pengaruh kompres hangat pada pasien hipertensi esensial di wilayah kerja Puskesmas Kahurpian Kota Tasikmalaya. Jurnal Kesehatan Bakti Tunas Husada, 13. https://doi.org/DOI: http://dx.doi.org/10.36465/jkbth.v13i1.37.

Soleha, M. (2012). 75342-ID-kadar-kolesterol-tinggi-dan-faktor-fakto. Jurnal Biotek Medisiana Indonesia, 1(2), 85-92. https://doi.org/https://doi.org/10.22435/jbmi.v1i2.1531.

Syagata, A. S., Rohmah, F. N., \& Khairani, K. (2021). Evaluasi pelaksanaan pengukuran tinggi badan oleh kader posyandu di Wilayah Yogyakarta. Jurnal Kebidanan Dan Keperawatan 'Aisyiyah, 17(2), 195-203. https://doi.org/10.31101/jkk.2311.

Wang, J., Ke, W., Bao, R., Hu, X., \& Chen, F. (2017). Beneficial effects of ginger Zingiber officinale Roscoe on obesity and metabolic syndrome: a review. Annals of the New York Academy of Sciences, 1398(1), 83-98. https://doi.org/10.1111/nyas.13375.

Wijaya, I. P. A. (2017). Factors affecting blood pressure increase in the event of 
hypertension indigenous community in Bualu. Caring, 1(04), 13-24.

World Health Organization. (2019). Noncommunicable diseases in South-East Asia.

Yandrizal, Y., Machmud, R., Noer, M., Hardisman, H., Afrizal, A., Lipoeto, N. I., Rahajeng, E., \& Pramudho, P. . K. (2016). The empowerment of integrated development post of non-communicable diseases in efforts to prevent and control non- communicable diseases. International Journal of Public Health Science (IJPHS), 5(3), 294. https://doi.org/10.11591/.v5i3.4799.

Susanti, Yulia., Anita, \& Santoso, D. Y. A. (2021). Perilaku cerdik penderita hipertensi dimasa pandemi covid-19. Jurnal Keperawatan, 13(1), 61-76.

Zadeh, J. B., \& Kor, N. M. (2014). Physiological and pharmaceutical effects of ginger ( Zingiber officinale Roscoe ) as a valuable medicinal plant. European Journal of Experimental Biology, 4(1), 87-90. https://www.researchgate.net/profile/Nasroallah_Moradi_kor/publication/268 226302_Physiological_and_pharmaceutical_effects_of_Ginger_(Zingiber_of ficinale_Roscoe)_as_a_valuable_medicinal_plant/links/5466ea6b0cf2397f78 29e78a.pdf 